\title{
The Spatial Extent of the Effect of Foreclosures on Crime
}

\author{
Seth B. Payton \\ Assistant Professor \\ School of Public and Environmental Affairs \\ Indiana University Public Policy Institute \\ Indiana University-Purdue University Indianapolis \\ Thomas D. Stucky \\ Associate Professor, \\ School of Public and Environmental Affairs \\ Indiana University Public Policy Institute \\ Indiana University-Purdue University Indianapolis \\ John R. Ottensmann \\ Professor Emeritus \\ School of Public and Environmental Affairs \\ Indiana University Public Policy Institute \\ Indiana University-Purdue University Indianapolis
}

\section{Contact Information:}

Seth B. Payton, Ph.D.

Assistant Professor

School of Public and Environmental Affairs

BS/SPEA Building 4076

$801 \mathrm{~W}$. Michigan St.

Indianapolis, IN 46202

sbpayton@iupui.edu

(317)278-4898

Keywords: externalities, foreclosures, crime, spatial analysis

This is the author's manuscript of the article published in final edited form as:

Payton, S. B., Stucky, T. D., \& Ottensmann, J. R. (2015). The spatial extent of the effect of foreclosures on crime. Social science research, 49, 288-298.

http://dx.doi.org/10.1016/j.ssresearch.2014.08.012 


\begin{abstract}
:
Although neighborhood stability has long been considered a substantial determinant of crime, foreclosures have not been the subject of concerted research among criminologists until recently. A number of recent studies have examined the linkage between home foreclosures and crime. Though generally finding a significant relationship, studies have used different approaches and units of analysis. This variation led us to examine the spatial extent to which foreclosures affect a relatively small surrounding area. In this paper, we consider the spatial extent of the foreclosure effect on crime by estimating fixed effect negative binomial models using geocoded UCR data for 2003-2008 and foreclosure data to predict crime counts using the number of foreclosures within various small area radii. Results show that, independently and jointly, foreclosures are a predictor of crime up to at least a distance of 2,250 feet. Importantly, that effect declines with distance. We conclude with a discussion of the implications of those findings.
\end{abstract}

\title{
1.Introduction
}

Scholarly interest in the external effects of foreclosures on neighborhood conditions has

increased over the past decade. The general consensus is that foreclosures contribute to neighborhood instability. ${ }^{1}$ Until recently, scholars have primarily focused on the external effect of foreclosures on property values (Immergluck and Smith, 2006a; Schuetz, Been, and Ellen, 2008; Harding, Rosenblatt, and Yao, 2009; Lin, Ronsenblatt, and Yao, 2009; Leonard and Murdoch, 2009). However, a rapidly expanding strand of scholarly research has examined the effects of foreclosures on crime (Acevedo, 2009; Arnio and Baumer, 2012; Bess, 2008; Baumer, Wolff, and Arnio, 2012; Ellen, Lacoe, and Sharygin, 2013;Goodstein and Lee, 2010; Harris, 2011; Immergluck and Smith 2006b; Jones and Pridemore, 2012; Katz, Wallace, and Hedberg2013; Kirk and Hyra 2012; Stucky, Ottensmann, and Payton 2012; Wallace, Hedberg and Katz, 2012; Williams, Galster, and Verma, 2013; Wolff, Cochran, and Baumer, 2013). Most research finds that more foreclosures are related to higher levels of crime. However, many of the studies examining the relationship between foreclosures and crime have employed relatively

\footnotetext{
${ }^{1}$ One example of a program acknowledging the neighborhood instability of foreclosures on neighborhoods is the federal Neighborhood Stabilization Program (NSP). The intergovernmental transfers of the NSP were directly related to relieving the negative neighborhood externalities of foreclosures (Immergluck 2011).
} 
large units of analysis, such as counties (Arnio, Baumer, and Wolff, 2012; Goodstein and Lee, 2010; Wolff, Cochran, Baumer, 2013) or census tracts (Immergluck and Smith, 2006b; Acevedo, 2009).

Larger units of analysis could mask the spatial extent of the foreclosure-crime relationship. Assessing the spatial relationship between foreclosures and crime at larger, commonly used, units of analysis (e.g., MSAs, Counties, and census tracts) is limited by at least three assumptions: (1) the relationship between two events is evenly distributed across the space of relatively large areas; (2) the relationship between two events is contained within and consistent with administrative or statistical boundaries of varying sizes and shapes; and (3) the magnitude of the effect of event $x$ (e.g., foreclosures) on event $y$ (e.g., crime) is not a function of distance between events.

Some studies have used smaller units of analysis (e.g., blockfaces, uniform spatial lattices). However, those studies have confronted the question of the spatial extent of foreclosure effects on crime by making a priori decisions about the distance at which that effect occurs (Cui, 2011; Ellen, Lacoe, and Sharygin, 2013; Stucky, Ottensmann, and Payton, 2012). The goal of the current study is to empirically test the distance within which foreclosures affect crime and the degree to which that effect decays with increasing distance. Specifically, our study examines the spatial extent of the effect of foreclosures on crime in an urban area by using a lattice of $500 \mathrm{x}$ 500 feet square cells that are uniformly distributed across space and radii of increasing distance.

Consistent with most previous studies, we generally find a significant and positive spatial relationship between foreclosures and crime. The magnitude of that relationship is greatest within the immediate $500 \times 500$ feet area and declines as the distance to foreclosures increases from the unit of analysis. The magnitudes of point estimates are similar when total crime is 
dissected into property crime and violent crime. However, the independent point estimates are less precise for violent crimes.

Our approach directly contributes to the literature that examines the spatial extent of externalities. Similar to the housing literature that has addressed the external effect of foreclosures on property values; we suggest that criminal justice practitioners can benefit from understanding the spatial extent at which foreclosure may affect crime. In particular, our findings indicate that the foreclosure-crime relationship is greatest in magnitude within very close proximity (i.e., within a 500 X 500 feet area), but the substantive impact of foreclosures extends to at least 2,250 feet and potentially as far as 3,250 feet.

There are several theoretical reasons foreclosures may be associated with crime. The following section examines the relevant theoretical and empirical literature linking crime and foreclosures, exploring why one might expect a small area effect of foreclosures that declines with distance. Then, we describe the data and modeling strategy for examining the spatial extent of that relationship. Next, we provide the results of our analysis. Finally, we discuss the implications of our findings.

\section{Relevant Literature Linking Crime and Foreclosures}

\subsection{Theoretical Framework}

Recent studies of foreclosures and crime have suggested several theoretical reasons to expect that foreclosures in an area will be associated with increased crime nearby (e.g. Wilson and Paulsen 2008; Kirk and Hyra 2012;Wallace et al 2012; Ellen et al 2013; Katz, et al 2013; Williams et al 2013; Wolff et al 2013). Universally, the foreclosure process involves several steps that occur over an extended period of time. To begin, the pre-foreclosure process is 
generally initiated when homeowners neglect timely mortgage payments. Homeowners are usually forced to vacate a property after an extended period of neglected payments. The vacancy of those properties is variable as lenders of foreclosed, vacant, properties seek buyers or renters.

Theories of crime focus on various aspects of the foreclosure process.For example, social disorganization theory posits that crime results from the inability of neighborhood residents to develop or maintain social cohesion and ties necessary to effectively maintain informal social control (Sampson and Groves, 1989; Shaw and Mckay 1972). From that perspective, homeowners facing foreclosure are likely to be under severe psychological stress and therefore may have reduced capacity or willingness to "invest" in maintaining neighborhood informal social control (Ellen et al 2013). The social organization of the neighborhood posited to be vital for maintaining social control is further disrupted when homeowners are forced out of their house (Harris, 2011; Pandit, 2011).

Similarly, broken windows theory suggests that physical disorder (e.g., deteriorating houses, unkempt lawns, visible trash and debris) sends a signal to would-be criminals that neighborhood residents care less about, or lack resources to effectively maintain, their neighborhood (Wilson and Kelling, 1982).Visible neighborhood deterioration may occur as homeowners facing foreclosure begin to defer maintenance on their properties (Katz et al 2013).Visible signs of decay are likely to increase as homes become vacant. The appearance of decay may cause contagion effects within an area as neighbors withdraw from social life due to increased fear of crime (Katz et al 2013) or reduced identification with the "neighborhood" (Wallace et al 2012).

Foreclosures may also increase opportunities for crime. Routine activities theory, which assumes that criminals are rational, suggests that offenders are drawn to accessible and desirable 
targets that lack adequate guardianship, reducing the likelihood of criminal apprehension (Cohen and Felson, 1979). The neglect and ultimate deterioration of foreclosed, or vacant, properties may send a signal to potential criminals that residents are less invested in the neighborhood (decreased guardianship) as the appearance of decay increases.Vacant homes may also be seen as suitable targets for theft or burglary (e.g., stripping of copper pipes or wiring), which could lead to higher crime in the immediate area (Spelman, 1993). Vacant homes may also become locations for squatters, drug-related crimes and prostitution (Ellen et al 2013). Arnio, et al (2012:1600) also note that foreclosures can cause shifts in secondary markets which can increase opportunities for property and violent crime as "more people come into contact with risky situations and by increasing the need for violent resolutions of unregulated transactions.”

From these perspectives, one might observe negative impacts on a neighborhood at various points in the foreclosure process. Homeowners facing foreclosure might begin to "withdraw” from community life, impacting informal social control. As homeowners withdraw, they might allow their houses to deteriorate. Property deterioration may lead to the perception of neighborhood decay, which may be associated with increased criminal activity.

There also is potential for the foreclosure process to lead to extended periods of vacancy. Vacancy over an extended period of time may lead to visible signs of deterioration. Thus, theory suggests that foreclosures may generally lead to crime, but some research suggests that the effects of foreclosures on crime are greater when homes are unoccupied (e.g. Cui 2011; Ellen et al 2013).

\subsection{Prior Empirical Research}

Methods used to study the relationship between foreclosures and crimes have varied. Immergluck and Smith (2006b) began the recent surge of related scholarly research by 
examining foreclosures and other determinants of census tract crime rates in Chicago, Illinois. Their results suggest that foreclosures affect census tract violent crime rates but not census tract property crime rates. From 2009 through 2013, at least sixteen published studies have examined the relationship between foreclosures and crime using various methods and levels of aggregation. For example, studies have used Metropolitan Statistical Areas (MSAs)(Pandit, 2011); counties (Arnio, Baumer, and Wolff, 2012; Goodstein and Lee, 2010;Wolff, Cochran, Baumer, 2013);police beats (Harris, 2011); census tract clusters (Kirk and Hyra2012, Williams, Galster, and Verma, 2013); census tracts (Arnio, and Baumer, 2012; Baumer, Wolff, and Arnio, 2012); and block groups (Katz, Wallace, and Hedberg, 2011; Wallace, Hedberg, and Katz, 2012). With a few exceptions (Kirk and Hyra 2012; Wolff, Cochran, and Baumer, 2013), research generally finds some relationship between foreclosures and crime, although that relationship may be of fairly short duration (Katz et al 2013), vary by neighborhood context (Arnio and Baumer 2012), and vary by crime type. Some studies find foreclosures affect property crime but not violent crime (e.g. Williams, Galster, and Verma 2013), violent crime but not property crime (e.g. Immergluck and Smith 2006b), or both (e.g. Stucky, Ottensmann, and Payton 2012). ${ }^{2}$

Although extant studies have generally examined fairly large units of analysis such as counties or cities, or sub-city units such as census tracts (which can be large and often vary substantially in size), it is possible that the spatial extent of the effect of foreclosures is small enough that those larger units of analysis may obscure the estimated effect of foreclosures on crime. We believe that the spatial extent of the effect of foreclosed residential properties on crime may extend only for relatively short distances. Our assertion is consistent with the few

\footnotetext{
${ }^{2}$ Some scholars argue that only certain types of crime (e.g., larceny and aggravated assault) occur as a result of foreclosures (Goodstein and Lee, 2010). Other scholars argue that social disorganization perspectives relate the lack of informal social control to all types of crime, including rape and murder (Kirk and Hyra, 2012).
} 
recent studies using smaller units of analysis. For example, Stucky, Ottensmann, and Payton (2012) employ negative binomial fixed effects (FENB) models to examine 1,000 x 1,000 feet grid cells in Indianapolis, Indiana. They find that foreclosures in contiguous grid cells have a positive effect on UCR reported violent and property crime (Stucky, Ottensmann, \& Payton, 2012). Using block faces as the unit of analysis and Ordinary Least Squares (OLS) and FENB models, Ellen, Lacoe, and Sharygin (2013) find that foreclosures on a blockface are associated with elevated crime in New York. Consistent with a potential distance decay effect, they note that the number of foreclosures in nearby blockfaces also increases crime to a lesser extent (Ellen, Lacoe, and Sharygin, 2013). Finally, Cui (2010) finds that foreclosures, after vacancy, are related to increased levels of both property and violent crime within a 250 feet radius when compared to an outer-radius (control effect) extending to 353 feet (250 feet * square root of 2) through a difference-in-difference modeling approach in Pittsburgh, PA. The Cui (2010) approach is quite innovative and allows the researcher substantial confidence in isolating a causal effect of foreclosures on crime. However, this approach assumes that the effect of foreclosures does not extend into the "control” area and the 250 feet radius appears to have been somewhat arbitrarily chosen.

In summary, theorists linking foreclosures and crime have often focused on social disorganization theory, broken windows theory, and routine activities theory. Both broken windows theory and routine activities theory suggest that the visible physical signs of decay associated with foreclosures (and ultimately vacant property in some instances) are expected to lead to increased perceptions of opportunity for crime and reduced surveillance. However, if the visible appearance of disorder associated with foreclosed and/or vacant homes is a determinant 
of increased crime, it seems reasonable that this effect would be localized to within a small area around the foreclosed property.

Similarly, social disorganization perspectives are often invoked as a mechanism that might link foreclosures and crime. If foreclosures lead to reductions in informal social control and collective efficacy due to the social and physical withdrawal of homeowners facing foreclosure, it seems reasonable that this effect is likely to be greatest in magnitude at relatively short distances from the affected home. However, the physical and social effects of foreclosures, especially if several are concentrated within a small area, may also have an effect on crime that extends beyond the immediate area.

Examination of small area effects in crime is a robust area of research (see Weisburd, Groff, and Yang, 2012 for a review of recent research on the micro-ecology of place and crime). For example, Taylor (1997) argues that street blocks create important "behavioral settings" for crime. Focusing on small areas around foreclosures would also make sense from the perspective of crime pattern theory, which argues that people operate within geographically finite “awareness spaces” (see Brantingham and Brantingham 1984, 1993), one of which is near their residence. Additionally, research has now well-documented that there are "hot spots" of crime which are typically very small areas (Sherman, Gartin, and Buerger, 1989). Tobler’s (1970) First Law of Geography, "Everything is related to everything else, but near things are more related to each other," also suggests that the effect of foreclosures on crime can be expected to operate over finite distances. Yet, the extant research on foreclosures has not explored the spatial extent of the effect of foreclosures on crime. Prominent theories of crime, though suggesting mechanisms for why they may be related, do not provide specific guidance on the distances at which one might expect to observe an impact of foreclosures on crime. Therefore, the goal of the current study is 
to examine the distance at which foreclosures affect crime and the degree to which that effect declines with increasing distance.

\section{Data and Methods}

\subsection{Study Area and Unit of Analysis}

We chose Indianapolis, Indiana to study the spatial extent of foreclosures on crime. The study area for this analysis is the former administrative boundaries of the Indianapolis Police Department (IPD). Several Marion County and City of Indianapolis government functions were consolidated in 1970. In 2008, IPD merged with the Marion County Sheriff's Department. To maintain consistency over time, our data do not extend beyond 2008. The former IPD administrative boundaries essentially correspond with the old central city boundaries, which is the district in which most reliable longitudinal data are available for this analysis. Therefore, we use only data that were collected by IPD prior to consolidating two data management systems. Additionally, limiting the study area to the former IPD boundaries increases comparability to other Midwestern and Northeastern cities.

We use a 500 x 500 feet grid cell unit of analysis to more effectively address the distance effect of foreclosures on crime. Map 1 illustrates the IPD service area and the grid cells used in the current study. Specifically, our dataset includes annual foreclosure listings and crime counts within 6,984 grid cells entirely contained within the former IPD service district. Our data span from 2003 to 2008. It should be noted that the study period of our analysis includes only the beginning of the recognition of the national housing crisis. In a national study, Immergluck (2011) found that the Indianapolis Metropolitan Statistical Area was among similar Midwestern metropolitan areas that experienced high initial foreclosures well before national attention on the 
2007 housing crisis. These data also allow us to employ a modeling strategy to mitigate annual unobserved heterogeneous effects.

\section{Map 1: Units of Analysis and Study Area}

Use of grid cells at the chosen resolution addresses the three limiting assumptions associated with larger, inconsistently sized units of analysis. First, smaller units of analysis (500 x 500 feet grid cells) mitigate the issue associated with aggregated data being evenly distributed across space. Smaller units of analysis more closely represent the spatial pattern of the underlying data. Second, usage of uniform grid cells addresses the limitation of using administrative or statistical boundaries that may be inconsistent with the spatial relationship of the phenomena being tested. Finally, the examination of the relationship of foreclosures and crimes within relatively small units of analysis (500 x 500 feet grid cells) allows for the test of distance effects within relatively short distances between two events (i.e., foreclosures [x] and crimes [y]).

\subsection{Crime Data}

Given the differences in past findings on violent versus property crimes of previous studies, we examine whether or not the distances at which foreclosures affect crime differs by crime type. Geocoded Uniform Crime Report (UCR) point data were obtained from the Indianapolis Police Department. We examine total, violent, and property UCR crime counts within each 500 x 500 feet cell. Violent crimes include homicide, rape, robbery, and aggravated assault. ${ }^{3}$ Property crimes include burglary, larceny, and motor vehicle theft. Total crime

\footnotetext{
${ }^{3}$ As one reviewer noted, rape counts in the UCR data suffer from under-reporting. Rapes represent a very small percentage of reported UCR violent crimes, however. Additionally, we do not have any reason to believe that
} 
includes all property and violent offenses. We calculated the number of crime and foreclosure incidents per cell, by year. Because property crimes occur much more frequently than violent crimes, total crime counts are relatively highly correlated with property crime counts.

\subsection{Foreclosure Data}

The foreclosure data are geocoded point locations of real estate owned (REO) residential properties listed for sale in the multiple listing service (MLS) database maintained by the Metropolitan Indianapolis Board of REALTORS (MIBOR). REO properties are properties for which lending institutions retain ownership after not selling at a foreclosure auction. REO properties also are the type of foreclosures (i.e., high probability of vacancy) that have had the greatest effect on crime in a previous study (Ellen, et.al.2013). REO properties are identified in the MIBOR MLS data as HUD-owned or bank-owned. MIBOR estimates that approximately 80 percent of single-family home listings are recorded in the MLS. ${ }^{4}$

\subsection{Modeling Strategy}

Our overarching hypothesis is that higher levels of nearby foreclosures lead to higher levels of crime. Based on that assumption, the annual number of crimes that occur in each grid cell is our dependent variable. A consequence of using count data as a dependent variable (especially at smaller units of analysis) is that those data are often skewed toward zero. Such a distribution violates the normality assumption necessary for linear regression. Additionally, there are multiple years during the study period in which zero crimes are recorded. Those observations

reported rates of rape changed during the period under consideration. Generally, we believe that inclusion or exclusion of rape counts in the violent and total crime indices is appropriate and unlikely to affect reported results. To maintain consistency, we include all data reflected in each UCR crime category.

${ }^{4}$ The percentage of REO properties listed in the MLS is likely higher than non-REO properties. 
lead to over-dispersion in a Poisson model. Due to our research question and structure of our data, we chose negative binomial fixed effects regression (see Greene, 2000; Osgood, 2000, Osgood \& Chambers, 2000). ${ }^{5}$

The purpose of the fixed effects estimator is to mitigate problems associated with omitted variable bias. The fixed effects model allows us to hold time-invariant neighborhood characteristics constant. By holding time-invariant characteristics constant, the potential bias associated with heterogeneous unobserved determinants across observations that may be correlated with both crime and foreclosures is reduced. That is, we have removed the influence of many unobserved factors that may simultaneously affect crime and foreclosures. As a result, we may make stronger inferences about the relationship between foreclosures and crime.

Based on a hypothesis consistent with Tobler’s (1970) First Law of Geography, we test the potential distance decay of the effect of foreclosures on crime. To do this, we examine the number of crimes within a 500 x 500 square feet grid cell (i.e., unit of analysis) and number of foreclosures within four mutually exclusive distance measures. The distance measures include the number of foreclosures within the grid cell; between the grid cell and 1,250 feet; from1,250 to 2,250 feet; and from 2,250 feet to 3,250 feet. All radii are calculated from the centroid of $500 \mathrm{x}$ 500 feet grid cell.

The use of uniform grid cells in this analysis is equivalent to including an area-based exposure variable. The small size of the grid cells makes explicitly including census-based residential population estimates or a similar measure as an exposure variable problematic. Rather than standardizing the risk of crime by residential population, our standardization of crime risk is

\footnotetext{
${ }^{5}$ The xtnbreg command in Stata, based on procedures developed by Hausmann, Hall, and Griliches (1984), was used to predict crimes in this study (StataCorp, 2009).
} 
based on physical area. ${ }^{6}$ That standardization is inherent in our units of analysis that do not vary in size or shape.

\section{Results}

\subsection{Descriptive analysis}

Table 1 shows the means, standard deviations, and ranges of variables used in our analyses. Standardized foreclosure measures are also shown to compare the variation of foreclosures by area (i.e., density of foreclosures). On average, there were approximately four crimes per grid cell during the study period. The number of crimes per grid cell range from zero to 260. Foreclosure listings per cell range from zero to 18 , with a mean of 0.31 . The mean number of foreclosures within various radii increases as distance increases. However, that increase is partly a function of the area within those ranges. Foreclosure density (converted to number of foreclosures/square mile) is fairly uniform across the various radii. However, standard deviations of foreclosure densities show variation increases as radius increases.

\section{Table 1: Descriptive Statistics}

\footnotetext{
${ }^{6}$ Exposure variables are often included in count models of crime to address potential variation in underlying risk of victimization. In models predicting counts of crimes for larger units of analysis (e.g., census tracts or counties), one may expect more crime where more people live and spend much of their time. Accordingly, residential population serves as a proxy for relative victimization risk in larger units of analysis. Residential population is not a suitable proxy for risk in our small area units of analysis, however. There are many grid cells in our analysis that include exclusively nonresidential areas where people may spend time, but do not live. Crime occurs in such areas even though the (residential) population is zero. In addition, there are many mixed use areas where few people live relative to the number of people that may come and go from these areas at any given point. Therefore, residential population or population-based measures such as the number of residences are problematic as exposure variables in this context. The use of the grid cell approach here accounts for risk of victimization by equalizing the physical area of exposure.
} 
Before examining the spatial extent of the effect of foreclosures on crime, it is important to address the directionality of the foreclosure-crime relationship. That is, we must address whether crimes lead to foreclosures or foreclosures lead to crimes.Although criminological theory suggests that increased levels of foreclosures lead to increased levels of crime (e.g., social disorganization and routine activities), it is not unreasonable to hypothesize that increased levels of crime may lead to increased levels of foreclosures. For instance, residents may exit a high crime area, choosing to stop payment and default on their mortgages. Another possibility is that mortgage companies execute the foreclosure process more rapidly in high crime areas due to perceived increased property risks. More expedient foreclosures in targeted high crime areas may reverse the direction of the relationship.

Table 2 shows the results testing for causal order. First, the lag of crimes(t-1year) is examined as a predictor of foreclosure listings within each $500 \times 500$ feet grid cell. Next, the temporal lag of foreclosures(t-1year) is examined as a predictor of crime by cell. Both models are negative binomial fixed-effects with year binary variables. A comparison of the two models supports the hypothesis that higher levels of foreclosures in the immediate area lead to higher levels of crime, as opposed to crimes leading to higher levels of foreclosures. Specifically, the coefficient for lagged foreclosures is a significant predictor of crime and lagged crime is not a significant predictor of current foreclosures. ${ }^{7}$ These results are consistent with the findings of a longitudinal study examining the foreclosure-crime relationship by Katz, Wallace, and Hedberg (2013), which also showed that temporally-lagged foreclosures were predictors of crime. ${ }^{8}$ Given

\footnotetext{
${ }^{7}$ Our methodology for determining directionality is consistent with Hipp, Tita, and Greenbaum (2009).

${ }^{8} \mathrm{We}$ also tested current foreclosures listings, lagged foreclosures sales, and current foreclosure sales in place of lagged foreclosures listings in preliminary models. Listings were consistently better predictors than foreclosure sales. Lagged foreclosure listings were better predictors of crime than current foreclosure listings. In fact, when current and lagged foreclosure listings were included in a preliminary model, lagged foreclosures were significant and current foreclosures were not significant.
} 
the structure of our data (i.e., annual counts), the temporally lagged foreclosure variable (t-1year) also ensures that the foreclosures were listed prior to crimes occurring in a cell.

\section{Table 2: Direction of Relationship between Crimes and Foreclosures}

Multicollinearity is another potential issue when examining the relationship of spatial externalities within multiple, small radii of an outcome. We intentionally chose several "short distance" radii to examine the spatial extent of foreclosures on crime. As a result, it should be noted that there is an inherent expectation of high collinearity between radii. Table 3 shows the correlation matrix of the number of foreclosures at each radius chosen for this study. As expected, there are relatively high correlations between many of the radii, suggesting that foreclosures are highly concentrated in some areas. These higher correlations suggest that we should consider the significance of independent and joint effects at each foreclosure distance measure.

\section{Table 3: Correlation Matrix for number of foreclosures by Radius}

Table 4 shows models for total crimes, property crimes, and violent crimes. The separation by types of crimes shows a similar relationship to the findings associated with foreclosures and total crimes. In all models, the distance measures are jointly significant $\left(\chi^{2}\right.$ at $p<0.05)$. The magnitude of the relationship is the greatest within the $500 \times 500$ feet grid cell across models. The distance of foreclosures to property crimes is independently significant $(p<0.05)$ to at least 1,250 feet (marginally significant anywhere between 1,250 feet and 2,250 
feet). Independent estimates for distance effects of foreclosures on violent crimes (approximately $37 \%$ of total crimes during study period) were much less precise. Although jointly significant to 2,250-3,250 feet, the magnitude and precision of estimates drops sharply past 1,250 feet. The weakness of estimates associated with violent crimes may partly be a function of the relative rarity of such crimes. Nevertheless, the empirical pattern of a distance decay effect is apparent across all models.

\section{Table 4: Total Crimes, Property Crimes, Violent Crimes and Foreclosures at Multiple Radii}

Figure 1 illustrates the distance decay of the relationship between foreclosures and violent and property crimes. Specifically, the percentage change in the incident rate of crimes for a one unit change in foreclosures at each radius, holding all else constant, is shown. One foreclosure within the $500 \times 500$ feet grid cell increases the incident rate of violent crimes and property crimes by 1.15 percent and 1.11 percent, respectively. That rate drops to about a 0.05 percentage increase in violent crimes and a 0.04 percentage increase in property crimes for each additional foreclosure at 2,250 to 3,250 feet.

\section{Discussion}

A large body of literature examines the extent to which foreclosures are a negative neighborhood externality. Several studies have examined the spatial extent of foreclosures from an implicit value perspective (i.e., hedonic framework). Recently, scholars have focused more attention on questions related to other potential neighborhood outcomes associated with foreclosures. We join the recent interest in empirically examining the relationship between foreclosures and crime. 
In the current study, we extend the existing literature that takes advantage of longitudinal micro-level foreclosure and crime data (Stucky, Ottensmann, and Payton, 2012; Katz, Wallace, and Hedberg, 2013). Using 500 x 500 feet grid cells, we explicitly measure uniform distance effects between foreclosures and crimes that may be masked by commonly used, larger, "neighborhood level" units of analysis that vary in shape and size. We estimate the relationship between the number of foreclosures listed during the entire previous year at various radii and crime. The magnitude of our results may be considered conservative as our estimates assume linear temporal effects over the year. ${ }^{9}$

Our study period extends from 2003 to 2008 in a Midwestern city that experienced substantial increases in foreclosures prior to the 2007 housing crisis. Foreclosure listings actually peaked in 2007 in Indianapolis. The fact that our findings are generally consistent with prior small area studies of foreclosures and crime, suggests that the time period did not affect the results. It is our contention that the distance effect of foreclosures on crime is expected to remain reasonably the same before, during, or after the housing crisis. Additionally, our fixed effects modeling strategy absorbs many of the time-invariant unobserved determinants that may have been correlated with both the number of foreclosures and crime. However, the extent to which the "housing crisis" may have affected the distance decay effects of foreclosures on crime that occurred during the study period is not clear and a question that can only be answered by examination of other places and during different study periods.

Generally, we find that the magnitude of the relationship between foreclosures listed in the previous year and total crime within the immediate area (1.15 percent increase in incident rate for each one unit change in foreclosure) is consistent with findings of previous studies that

\footnotetext{
${ }^{9}$ Katz et.al. (2013) find a relatively shorter-term effect of each additional foreclosure starts (less than three months).
} 
examine the same relationship at relatively small units of analysis. The magnitude of the relationship is considerably higher in the immediate area (500 x 500 feet grid cell). However, our analysis shows that foreclosures exert a negative externality through increased crime that extends beyond the immediate area. Though the general distance effect may vary from one urban area to another, our findings suggest that detectable effects of foreclosures on crime may extend beyond a few city blocks (e.g., 2,250 feet (.43 miles) to 3,250 feet (0.62 miles).

The recent literature examining the relationship between foreclosures and crime reveals mixed results when total crimes are separated into types of crimes (e.g. violent and property). Some studies find no relationship between foreclosures and property crimes, but a significant positive relationship between foreclosures and violent crimes (Immergluck and Smith 2006b). Other studies find a significant positive relationship between foreclosures and property crimes but not violent crimes (Williams, Galster, and Verma 2013). Our study finds that foreclosures have positive significant relationships with both property and violent crimes (consistent with Stucky, Ottensmann, and Payton 2012). As with total crime, separate models indicate that the effect of both types of crime declines substantially for each unit change in foreclosures as distance increases. The relationship between foreclosures and violent crimes is much less precisely estimated. In other words, the empirical magnitude of the effects of foreclosures on violent and property crimes declines at a similar rate as distance increases, but the statistical significance of foreclosures on violent crime is lower due to larger standard errors.

In this study we focused on nonlinear foreclosure effects that declined with distance. Another useful line of inquiry would be to consider nonlinear, cumulative effects of foreclosures on crime within an area. It seems reasonable to assume that a single foreclosure in an area may not have nearly the impact that multiple foreclosures in a given block might have. Cumulative, 
nonlinear effects of foreclosures would also make sense from social disorganization, broken windows, and routine activities theory, which focus on reduced informal social control and surveillance, and increased opportunities for crime associated with foreclosures. A few recent studies of foreclosures suggest that crimes do not increase linearly with foreclosures in a given area. ${ }^{10}$ For instance, Ellen et.al (2013) find that the effect of foreclosures on crime increases demonstrably as the number of foreclosures on a street segment increases to three or more. Additionally, Arnio, Baumer and Wolf (2012) found that an additional foreclosure in a high foreclosure county had a greater effect on crime than an additional foreclosure in a low foreclosure county.

Though direct examination of nonlinear effects was beyond the scope of the current study, estimates from the current study suggest that concentrations of foreclosures have significant impacts on rates of crime. For example, 2.9 percent of the observations in our study experienced three or more foreclosure listings in the immediate area (500 x 500 feet square area) during the previous year. The predicted number of total crimes for those observations is 3.5 percent higher $\left(100 *\left[1.0114^{3}-1\right]\right)$ than immediate areas with zero foreclosures. The predicted number of crimes is 5.5 percent higher in the immediate area ( 500 x 500 feet grid cells) when the area between 1,250 feet and the grid cell experienced 20 or more foreclosures (4.1 percent of the sample). In that example, three foreclosures in the immediate cell and an additional 20 foreclosures within 1,250 feet of the cell are predicted to cumulatively increase the incidence of crime by 9.0 percent compared to similar cells with zero foreclosures within 1,250 feet. Thus, our results suggest that high concentrations of foreclosures are expected to have a demonstrable

\footnotetext{
${ }^{10}$ We are grateful to an anonymous reviewer for suggesting additional attention to this issue.
} 
impact on crimes locally and we believe that additional exploration of nonlinear, concentration effects of foreclosures would be a fruitful avenue for future studies.

Our findings are also consistent with recent research on the micro-ecology of place as it relates to crime (e.g. Weisburd et al 2012). Crimes tend to be higher in areas near foreclosures. Perhaps not surprisingly, the immediate area (e.g., within a $500 \mathrm{x} 500$ feet area) is likely to experience the greatest impact on levels of crime. However, a detectable impact of foreclosures on crime extends as far as 3,250 feet. One limitation of our study is that we could not directly test the mechanisms by which social disorganization, broken windows, and routine activities theory connect foreclosures and crime (i.e. direct measures of surveillance, disorder, informal social control). Future studies could explore these relationships with more direct measures.

We also used an artificial unit of analysis—-500X500 feet grid cells, which facilitated the exploration of distance effects. Ideally one would like to have a unit of analysis that matches the social reality of the world people inhabit. This has been an ongoing struggle in macro-level research (see Hipp and Boessen 2013 for a discussion), especially as it relates to what constitutes a neighborhood. The traditional approach in social disorganization theory is that a neighborhood is a discrete area that is somewhere along a continuum of organization or disorganization. Yet, Hipp and Boessen (2013) note that residents tend to view themselves as the center of their neighborhood (in what they call "egohoods") and they argue that neighborhoods are not discrete entities but rather overlapping waves that ripple throughout a city. Hipp and Boessen (2013) also note that research shows there are distance decay functions in social ties among area residents and travel to crime patterns for criminals. Our study found distance decay effects of one factor likely to be associated with physical and social disorder (i.e., foreclosures). The incorporation of the concept of egohoods into social disorganization and other macro-level theories of crime 
seems a fruitful avenue for future theorizing. Our study provides empirical evidence that there are good reasons to investigate this further and perhaps begin to explore ways to explicitly incorporate physical distance within macro-level theories of crime and redefine what constitutes one's "neighborhood". Though beyond the scope of this study, explicit consideration of how people conceptualize the extent of their neighborhood and awareness space would benefit extant macro-level theories of crime and provide direct guidance on how far one would expect to see effects of physical and social disorder extend.

Practically, our results suggest yet another justification for recent efforts, such as the federal Neighborhood Stabilization Program, to revitalize neighborhoods that experience high levels of foreclosure activity. In addition, when stakeholders consider proposals for public interventions to address community impacts of foreclosures, they should consider that properties located outside areas with high concentrations of foreclosurescan experience negative external effects. Specifically, our findings indicate that properties on the edge of high foreclosure concentrations could experience increased crime. This suggests that police, community organizations, and residents should monitor not only the areas disproportionately affected by foreclosures, but also neighborhoods near greater concentrations of foreclosures. 


\section{References}

Acevedo, Luis G. 2009. “An Empirical Analysis of the Impact of Home Foreclosure on the Crime Rate: Evidence in Atlanta, GA.” Research paper, Economics. Smithfield, RI: Bryant University.

Arnio, Ashley, and Eric P. Baumer. 2012. "Demography, Foreclosure, and Crime: Assessing Spatial Heterogeneity in Contemporary Models of Neighborhood Crime Rates.” Demographic Research 26:449-486.

Arnio, Ashley N., Eric P. Baumer, Kevin T. Wolff. 2012. "The Contemporary Foreclosure Crisis and US Crime Rates. Social Science Research. 41(6): 1598-1614.

Baumer, Eric P., Kevin T. Wolff, and Ashley N. Arnio. 2012. “A Multicity Neighborhood Analysis of Foreclosure and Crime. Social Science Quarterly. 93(3): 559-865.

Bess, Michael. 2008. "Assessing the Impact of Home Foreclosures in Charlotte Neighborhoods.” Geography and Public Safety 1(3): 2-5.

Brantingham, Paul J., and Patricia L. Brantingham.1984.Patterns in Crime. New York: Macmillan.

Brantingham, Patricia L., andBrantingham, Paul. J. 1993. Nodes, Paths and Edges:

Considerations on the Complexity of Crime and the Physical Environment. Journal of Environmental Psychology 13: 3-28.

Cohen, Lawrence and Marcus Felson. 1979. Social Change and Crime Rate Trends: A Routine Activity Approach. American Sociological Review. 44(4): 588-608.

Cui, Lin. 2011. “Foreclosure, Vacancy, and Crime.”Unpublishedmanuscript.Available at (http://www.pitt.edu/ lic29/Foreclosure, Vacancy and Crime.pdf).

Ellen, Ingrid Gould, Johanna Lacoe, and Claudia Ayanna Sharygin.2013.“Do Foreclosures Cause Crime?” Journal of Urban Economics. 74: 59-70

Goodstein, Ryan M., and Yan Y. Lee. 2010. Do Foreclosures Increase Crime?Federal Deposit Insurance Corporation Center for Financial Research Working Paper, No. 2010-05.Available at (http://www.fdic.gov/bank/analytical/cfr/2010/wp2010/CFR_WP_2010_05goodsteinlee.pdf).

Greene, William H. 2000. Econometric Analysis, $4^{\text {th }}$ edition. Upper Saddle River, NJ: Prentice Hall.

Harding, John P., Eric Rosenblatt, and Vincent W. Yao. 2009. "The Contagion Effect of Foreclosed Properties.” Journal of Urban Economics 66(3): 164-178. 
Harris, Paul E. (Lish). 2011. "The Criminal Consequences of Changes in Neighborhood Structure Due to Home Foreclosure: A Theoretical Discussion.” Chapter in In Economic Crisis and Crime, edited by Mathieu Deflem. Bingley, UK: Emerald.

Hausman, Jerry, Bronwyn H. Hall, and ZviGriliches. 1984. "Econometric Models for Count Data with an Application to the Patents-R\&D Relationship.” Econometrica 52(4): 908-938.

Hipp, John. R., and AdamBoessen. 2013. “Egohoods as Waves Washing across the City: a New Measure of “Neighborhoods”. Criminology51(2): 287-327.

Hipp, John R., George E. Tita, and Robert T. Greenbaum. 2009. "Drive-bys and Trade-ups: Examining the Directionality of the Crime and Residential Instability Relationship.” Social Forces 87(4): 1777-1812.

Immergluck, Dan and GeoffSmith. 2006a. "The External Costs of Foreclosure: The Impact of Single-Family Mortgage Foreclosures on Property Values.” Housing Policy Debate 17(1): 57-79.

Immergluck, Dan and Geoff Smith.2006b.“The Impact of Single Family Mortgage Foreclosures on Neighborhood Crime.”Housing Studies, 21(6): 851-866.

Immergluck, Dan. 2010. Neighborhoods in the Wake of the Debacle, Intrametropolitan Patterns of Foreclosed Properties, Urban Affairs Review 46(1): 3-36.

Jones, Roderick W., and William Alex Pridemore. 2012. The Foreclosure Crisis and Crime: Is Housing-Mortgage Stress Associated with Violent and Property Crime in U.S. Metropolitan Areas? Social Science Quarterly. 93(3): 671-691.

Katz, Charles M., Danielle Wallace, and E.C. Hedberg. 2013. “A Longitudinal Assessment of the Impact of Foreclosure on Neighborhood Crime.” Journal of Research in Crime and Delinquency 50:359-398.

Kirk, David, and Derek Hyra. 2012. "Home Foreclosures and Community Crime: Causal or Spurious Association?” Social Science Quarterly. 93(3): 648-670.

Leonard, Tammy and James C. Murdoch. 2009. "The Neighborhood Effects of Foreclosures.” Journal of Geographic Systems 11(4): 317-332.

Lin, Zhenguo, Eric Rossenblatt, and Vincent W. Yao. 2009. "Spillover Effects of Foreclosures on Neighborhood Property Values.” Journal of Real Estate Finance and Economics 38(4): 387407.

Osgood, D. Wayne. 2000. "Poisson-based Regression Analysis of Aggregate Crime Rates.” Journal of Quantitative Criminology 16(1): 21-43.

Osgood, D. Wayne, and Jeff M. Chambers. 2000. "Social Disorganization Outside the Metropolis: An Analysis of Rural Youth Violence. Criminology 38(1): 81-115. 
Pandit, Caaminee. 2011. "The Impact of Foreclosures on Crime in American Cities.” Sociological Insight 3: 82-109.

Sampson, Robert J., and W. Byron Groves. 1989. "Community Structure and Crime: Testing Social Disorganization Theory.” American Journal of Sociology 94(4): 774-802.

Schuetz, Jenny, Vicki Been, and Ingrid Gould Ellen. 2008. "Neighborhood Effects of Concentrated Mortgage Foreclosures.” Journal of Housing Economics 17(4): 306-319.

Shaw, Clifford R., and Henry D. McKay [1942] 1972. Juvenile Delinquency and Urban Areas, rev. ed. Chicago, IL: University of Chicago Press.

Sherman, Lawrence W., Patrick R. Gartin, and Michael E. Buerger. 1989. "Hot Spots of Predatory Crime: Routine Activities and the Criminology of Place*." Criminology 27: 27-56.

Spelman, William. 1993. “Abandoned Buildings: Magnets for Crime?” Journal of Criminal Justice 21(5): 481-495.

StataCorp. 2009.Stata Longitudinal-Data/Panel-Data Reference Manual: Release 11. College Station TX: Stata Press.

Stucky, Thomas D., John R. Ottensmann, and Seth B. Payton. 2012. The Effect of Foreclosures on Crime in Indianapolis, 2003-2008. Social Science Quarterly. 93(3): 602-624

Taylor, Ralph. B. 1997. Social Order and Disorder of Street Blocks and Neighborhoods: Ecology, Microecology, and the Systemic Model of Social Disorganization. Journal of Research in Crime and Delinquency34: 113-155.

Tobler, Waldo R. 1970. A Computer Movie Simulating Urban Growth in the Detroit Region. Economic Geography, 46, 234-40.

Wallace, Danielle, E. C. Hedberg, and Charles M. Katz. 2012. The Impact of Foreclosures on Neighborhood Disorder and During the Housing Crisis: Testing the Spiral of Decay. Social Science Quarterly. 93(3): 625-647.

Weisburd, David L., Elizabeth R. Groff, and Sue-Ming Yang. 2012.TheCriminology of Place: Street Segments and our Understanding of the Crime Problem. Oxford University Press.

Williams, Sonya, George Galster, and NanditaVerma. 2013. "Home Foreclosures and Neighborhood Crime Dynamics.” Housing Studies.Published online 18 June 2013. DOI:10.1080/02673037.2013.803041

Wilson, James Q., and George L. Kelling. 1982. “The Police and Neighborhood Safety: Broken Windows.” Atlantic Monthly 127: 29-38. 
Wilson, Ronald E., and Derek J. Paulsen.2008. "Foreclosures and crime: A geographical perspective." Geography \& Public Safety 1.3: 1-2.

Wolff, Kevin T., Joshua C. Cochran, and Eric P. Baumer. 2013. "Reevaluating Foreclosure Effects on Crime during the “Great Recession”." Journal of Contemporary Criminal Justice Published online 15 November 2013. DOI: 10.1177/1043986213509025. 


\section{Tables}

Table 1: Descriptive Statistics

\begin{tabular}{lrrrr}
\hline Variable & Mean & Std. Dev. & Min & Max \\
\hline \multicolumn{1}{r}{ Analyzed Variables } \\
Total Crime & 4.11 & 8.27 & 0 & 260 \\
Violent Crime & 1.5 & 3.75 & 0 & 184 \\
Property Crime & 2.61 & 5.67 & 0 & 240 \\
Number foreclosures Cell & 0.31 & 0.79 & 0 & 18 \\
Number of Foreclosures between Cell\& 1250 & 5.69 & 6.87 & 0 & 51 \\
Number of Foreclosures between 1250 \& 2250 & 13.37 & 12.80 & 0 & 94 \\
Number of Foreclosures between 2250 \& 3250 & 20.80 & 17.16 & 0 & 134 \\
\multicolumn{1}{c}{ Standardized Foreclosure Variables (foreclosures/mile) } \\
Foreclosure Density Cell & 34.2 & 87.71 & 0 & 2007.25 \\
Foreclosures Density $<$ 1250 & 34.07 & 41.14 & 0 & 323.72 \\
Foreclosures Density $<$ 2250 & 33.95 & 32.87 & 0 & 220.86 \\
Foreclosures Density $<3250$ & 33.75 & 28.38 & 0 & 188.19 \\
\hline
\end{tabular}

Table 2: Direction of Relationship between Crimes and Foreclosures

\begin{tabular}{lcc}
\hline \multirow{2}{*}{ VARIABLES } & \multicolumn{2}{c}{ Dependent Variables } \\
\cline { 2 - 3 } Total Crime(t-1) & Foreclosure & Crime \\
Total Foreclosure Listings (t-1) & -0.0025 & -- \\
& $(0.0027)$ & $0.0139 * * *$ \\
Year 2005 & -- & $(0.0043)$ \\
& $0.1687^{* * *}$ & $0.0392^{* * *}$ \\
Year 2006 & $(0.0297)$ & $(0.0100)$ \\
& $0.3147^{* * *}$ & $0.0802^{* * *}$ \\
Year 2007 & $(0.0288)$ & $(0.0099)$ \\
& $0.4782^{* * *}$ & $0.0966^{* * *}$ \\
Year 2008 & $(0.0280)$ & $(0.0099)$ \\
& $0.4071^{* * *}$ & $0.0313^{* * *}$ \\
Constant & $(0.0284)$ & $(0.0101)$ \\
& $2.2404^{* * *}$ & $2.4008^{* * *}$ \\
Observations & $(0.1697)$ & $(0.0297)$ \\
Number of zone & & \\
Wald $\chi^{2}$ & 18,220 & 34,920 \\
Log Likelihood & 3,644 & 6,984 \\
\hline
\end{tabular}

Standard errors in parentheses

${ }^{* * *} \mathrm{p}<0.01,{ }^{* *} \mathrm{p}<0.05,{ }^{*} \mathrm{p}<0.10$ 
Table 3: Correlation of Number of Foreclosures at Each Radius

\begin{tabular}{lccc}
\hline & & \multicolumn{2}{c}{ Between } \\
\cline { 3 - 4 } & Cell (500x500ft) & Cell \&1,250ft & $1,250 \mathrm{ft} \& 2,250 \mathrm{ft}$ \\
\hline Between Cell\& 1,250ft & 0.43 & & \\
Between 1,250ft \&2,250ft & 0.34 & 0.73 & \\
Between 2,250ft \&3,250ft & 0.28 & 0.60 & 0.79 \\
\hline
\end{tabular}

Table 4: Violent Crimes, Property Crimes, and Number of Foreclosures at Multiple Radii

\begin{tabular}{lccc}
\hline \multicolumn{1}{c}{ VARIABLES } & Total Crimes & Violent Crimes & Property Crimes \\
\hline Cell (500x500ft) & $0.0114^{* * *}$ & $0.0114^{*}$ & $0.0110^{* *}$ \\
Between Cell \& 1,250ft & $(0.0013)$ & $(0.0064)$ & $(0.0052)$ \\
& $0.0027^{* * *}$ & 0.0022 & $0.0023^{* *}$ \\
Between 1,250ft \&2,250ft & $(0.0010)$ & $(0.0014)$ & $(0.0012)$ \\
& $0.0017^{* * *}$ & 0.0010 & $0.0018^{* *}$ \\
Between 2,250ft \&3,250ft & $(0.0001)$ & $(0.0010)$ & $(0.0008)$ \\
& 0.0004 & 0.0005 & 0.0004 \\
Year 2005 & $(0.0005)$ & $(0.0008)$ & $(0.0006)$ \\
& $0.0251^{* * *}$ & $0.0652^{* * *}$ & 0.0120 \\
Year 2006 & $(0.0105)$ & $(0.0170)$ & $(0.0124)$ \\
& $0.0585^{* * *}$ & $0.0393^{* *}$ & $0.0797^{* * *}$ \\
Year 2007 & $(0.0112)$ & $(0.0177)$ & $(0.0131)$ \\
& $0.0668^{* * *}$ & $0.0801^{* * *}$ & $0.0668^{* * *}$ \\
Year 2008 & $0.0122)$ & $(0.0194)$ & $(0.0142)$ \\
& -0.0113 & 0.0054 & -0.0161 \\
Constant & $(0.0144)$ & $(0.0230)$ & $(0.0166)$ \\
& $2.3538^{* * *}$ & $1.901^{* * *}$ & $2.1913^{* * *}$ \\
Observations & $(0.0317)$ & $(0.0436)$ & 0.0376 \\
Number of zone & & & \\
Wald $\chi^{2}$ & 34,920 & 29,320 & 34,250 \\
$\chi^{2}$ joint significance distance & 6,984 & 5,864 & 6,850 \\
S Stand & $166.10^{* * *}$ & $67.08^{* * *}$ & $152.44^{* * *}$ \\
\end{tabular}

Standard errors in parentheses

$* * * \mathrm{p}<0.01, * * \mathrm{p}<0.05, * \mathrm{p}<0.10$ 


\section{Figures}

Figure 1: Percentage Change in Violent and Property Crimes for One Unit Change in Foreclosures

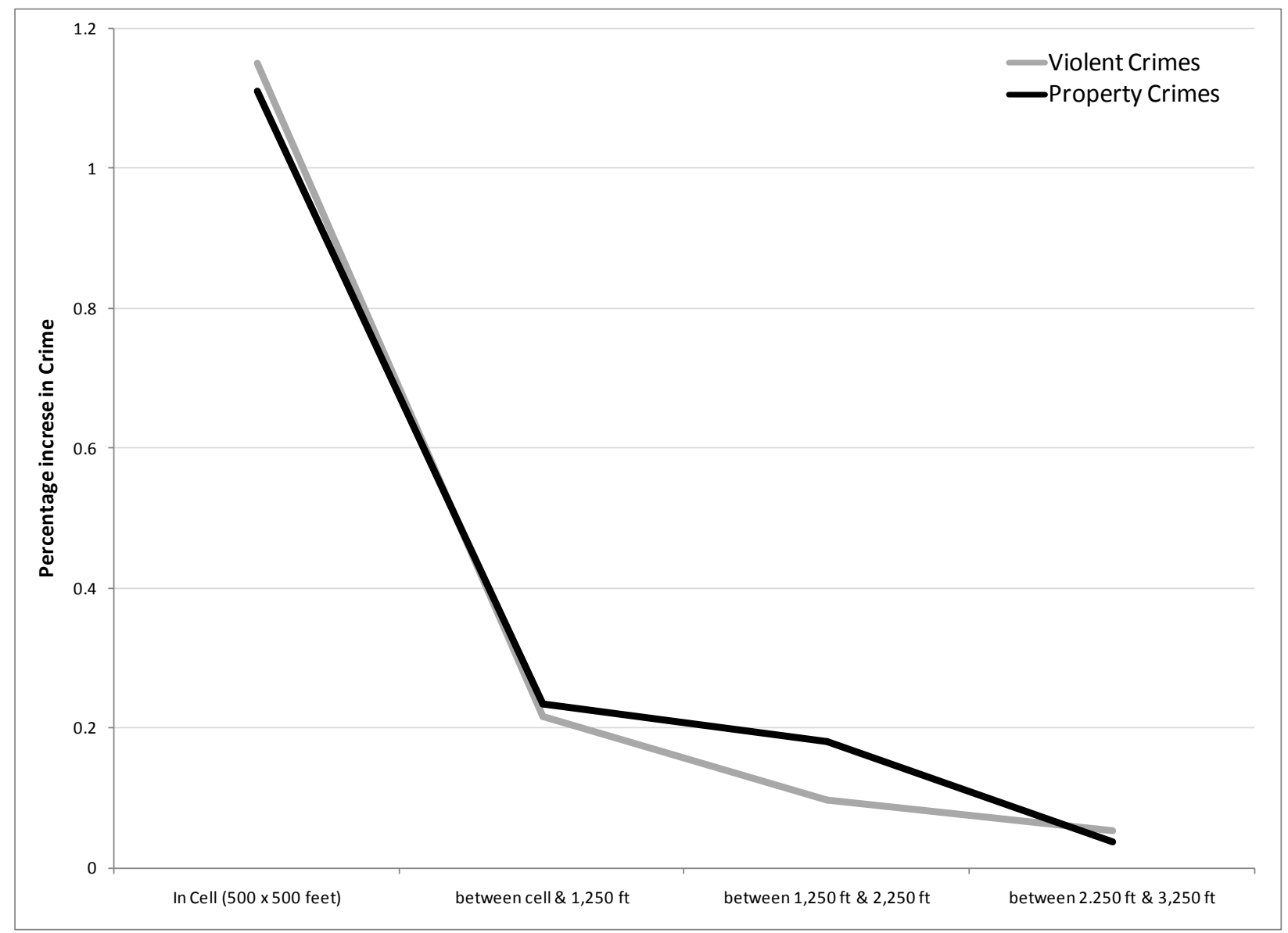

*Jointly significant at $p<0.05$ 


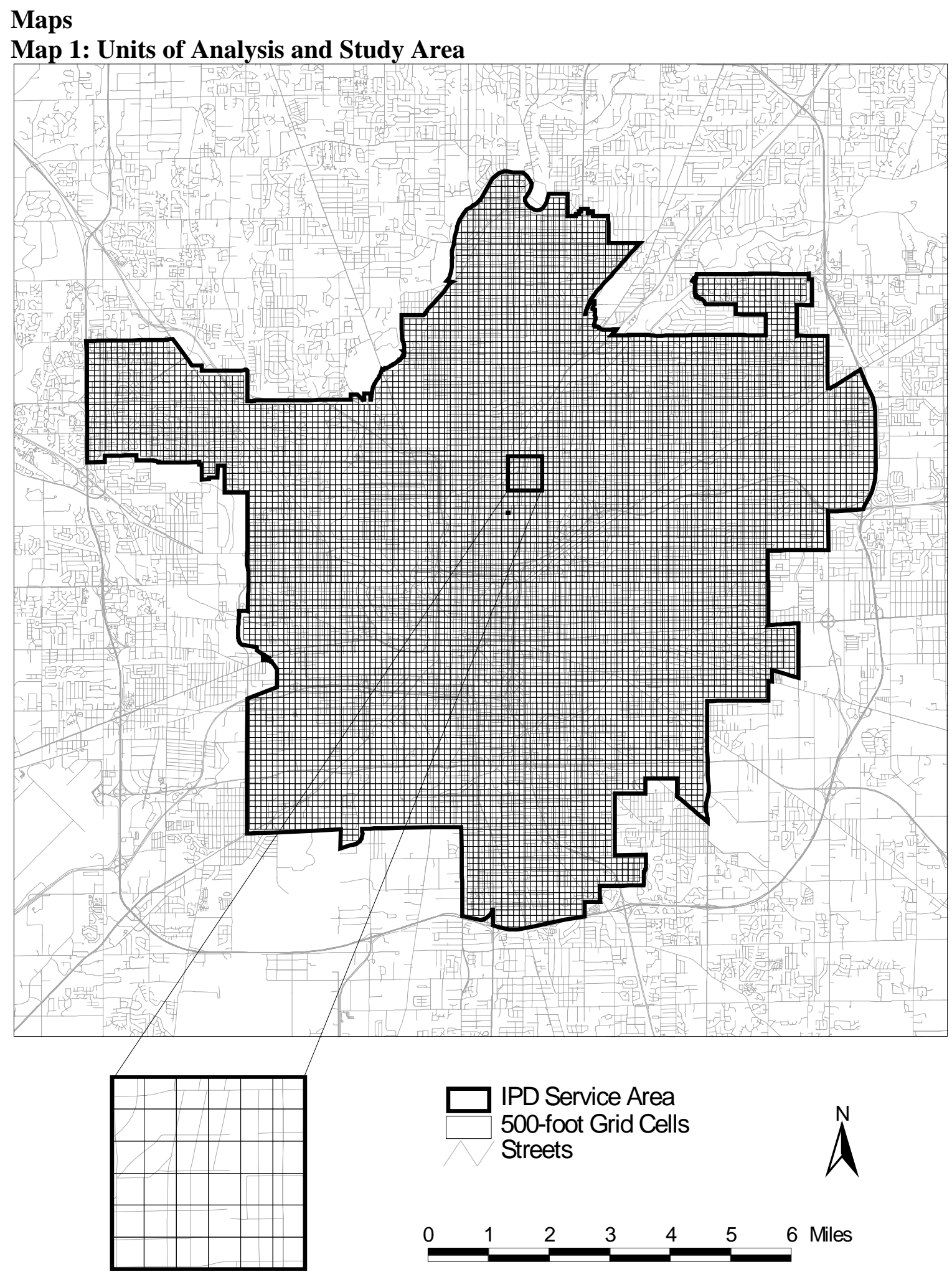

